\title{
Signal peptide cleavage is essential for surface expression of a regulatory $T$ cell surface protein, leucine rich repeat containing 32 (LRRC32)
}

Derek V Chan ${ }^{1,6^{*}+}$, Ally-Khan Somani ${ }^{1,7 \dagger}$, Andrew B Young ${ }^{1}$, Jessica V Massari ${ }^{1}$, Jennifer Ohtola ${ }^{1}$, Hideaki Sugiyama ${ }^{1,3}$, Edina Garaczi ${ }^{1,2}$, Denise Babineau ${ }^{4}$, Kevin D Cooper ${ }^{1,5}$ and Thomas S McCormick ${ }^{1}$

\begin{abstract}
Background: Elevated numbers of regulatory $T$ cells $\left(T_{\text {regs }}\right)$ have been implicated in certain cancers. Depletion of $T_{\text {regs }}$ has been shown to increase anti-tumor immunity. $T_{\text {regs }}$ also play a critical role in the suppression of autoimmune responses. The study of $\mathrm{T}_{\text {regs }}$ has been hampered by a lack of adequate surface markers. Leucine Rich Repeat Containing 32 (LRRC32), also known as Glycoprotein A Repetitions Predominant (GARP), has been postulated as a novel surface marker of activated $T_{\text {regs. }}$. However, there is limited information regarding the processing of LRRC32 or the regulatory phenotype and functional activity of $T_{\text {regs }}$ expressing LRRC32.

Results: Using naturally-occurring freshly isolated $T_{\text {regs }}$, we demonstrate that low levels of LRRC32 are present intracellularly prior to activation and that freshly isolated $L R R C 32^{+} T_{\text {regs }}$ are distinct from $L R R C 32^{-} T_{\text {regs }}$ with respect to the expression of surface CD62L. Using LRRC32 transfectants of HEK cells, we demonstrate that the N-terminus of LRRC32 is cleaved prior to expression of the protein at the cell surface. Furthermore, we demonstrate using a construct containing a deleted putative signal peptide region that the presence of a signal peptide region is critical to cell surface expression of LRRC32. Finally, mixed lymphocyte assays demonstrate that LRRC32 ${ }^{+} \mathrm{T}_{\text {regs }}$ are more potent suppressors than LRRC32- $T_{\text {regs. }}$

Conclusions: A cleaved signal peptide site in LRRC32 is necessary for surface localization of native LRRC32 following activation of naturally-occurring freshly-isolated regulatory T cells. LRRC32 expression appears to alter the surface expression of activation markers of T cells such as CD62L. LRRC32 surface expression may be useful as a marker that selects for more potent $T_{\text {reg }}$ populations. In summary, understanding the processing and expression of LRRC32 may provide insight into the mechanism of action of $T_{\text {regs }}$ and the refinement of immunotherapeutic strategies aimed at targeting these cells.
\end{abstract}

\section{Background}

Leucine Rich Repeat Containing 32 (LRRC32), also known as Glycoprotein A Repetitions Predominant (GARP), is a member of the leucine rich repeat family that exhibits evolutionary similarity to Toll-like receptors [1]. It was initially localized to chromosome 11q1314 but has since been further defined and mapped to the 11q13.5-14 region [2-5]. The Lrrc32 gene consists of

\footnotetext{
* Correspondence: derek.chan@uhhospitals.org

† Contributed equally

1 Department of Dermatology, University Hospitals Case Medical Center and Case Western Reserve University, Cleveland, OH, 44106 USA
}

Full list of author information is available at the end of the article two coding exons and is expressed as two different transcripts, 4.4 and $2.8 \mathrm{~kb}$ in length [3]. The homologous mouse gene has been found in the $7 F$ chromosomal region and shares high sequence homology to human LRRC32 [2,6]. The homologous gene in grass carp (Ctenopharyn-godonidellus) shares 37\% homology with human Lrrc32, and it has been found to contain transcription factor binding sites for AP1, IRF-1, IRF4, IRF7 , and NFAT, which are critical for the expression of many cytokines, suggesting a role for LRRC32 in the immune system [7].

Lrrc32 has been shown, via Northern blot, to be expressed in placenta, lung, kidney, heart, liver, skeletal muscle, and pancreas but not brain [3]. Furthermore,

\section{() Biomed Central}


Lrrc32 mRNA is also highly expressed in activated $\mathrm{T}_{\text {regs }}$ and appears to mediate FoxP3 expression, enabling $\mathrm{T}_{\text {regs }}$ to suppress effector cell activation [8-10]. With respect to the structural aspects of LRRC32, a sequence analysis of the human 662 amino acid protein product initially suggested that it was almost entirely extracellular, with 20 leucine rich repeats in the extracellular portion of the protein followed by a hydrophobic stretch of proteins thought to be a transmembrane domain, followed by a short cytoplasmic domain consisting of 15 amino acids [3]. Sequence analysis by SignalP 3.0 revealed a putative $\mathrm{N}$ terminal signal peptide with a likely cleavage site after residue 17 of the pro-peptide. Surface localization of this protein in transfected cells has been confirmed $[8,9,11]$. N-linked glycosylation has also been reported to play a role in post-translational processing of this protein [3].

LRRC32 is expressed on the surface of expanded $\mathrm{T}_{\text {regs }}$, and IL-2-expanded LRRC32-positive CD25 hi cells are more suppressive than their IL-2-expanded LRRC32negative counterparts [10]. Inhibition of LRRC32 expression using lentiviral or siRNA strategies in expanded $\mathrm{T}_{\text {reg }}$ populations results in decreased suppressive capacity of the targeted cells [10]. The studies summarized above used previously-expanded $\mathrm{T}_{\text {regs }}$. Therefore, they do not address the suppressive capacity of freshly isolated naturally-occurring LRRC $32^{+}$and LRRC32- subpopulations of $\mathrm{CD} 25^{\text {hi }}$ regulatory cells. Although addition of TGF- $\beta$ to LRRC $32^{-}$CD $25^{-}$cells induced FoxP3 expression, LRRC32 was not upregulated, and cells treated in this manner were unable to suppress the proliferation of $\mathrm{T}$ effectors, suggesting that the upregulated expression of FoxP3 was not sufficient to confer suppressive capacity on effector cells [10]. Furthermore, over-expression of FoxP3 on activated $\mathrm{CD} 4^{+} \mathrm{T}$ cells did not induce expression of LRRC32 on the cell surface [10]. Finally, it has also recently been reported that LRRC32 binds latency-associated protein (LAP) and that surface expression of LAP, in turn, is upregulated on activated $\mathrm{T}_{\text {regs }}$ in conjunction with LRRC32 upregulation [11-13]. As previously reported, $\mathrm{T}_{\text {regs }}$ may also use cell-surface bound transforming growth factor beta (TGF- $\beta$ ) to directly inhibit $\mathrm{T}_{\text {eff }}$ growth in a cell to cell contact dependent manner [14].

Naturally-occurring $\mathrm{T}_{\text {regs }}$ are currently defined by the phenotypic expression of numerous surface markers including CD4, CD25, CD127, CD49, GITR, CTLA4, and the intracellular transcription factor FoxP3 [15-22]. Since no single marker identifies the $\mathrm{T}_{\text {reg }}$ subset, the potential use of LRRC32 as an additional surface marker for potent $T_{\text {regs }}$ is of interest. We surmised that LRRC32 surface expression on $\mathrm{T}_{\text {regs }}$ might have utility for the selection of $\mathrm{T}_{\text {regs }}$ for functional studies as well as differentiation and activation studies. Although previous studies have looked at the functional suppressive capacity of $T_{\text {regs }}$ that were expanded with cytokines such as IL-2, we chose to study the suppressive capacity of naturally-occurring freshly isolated activated $\mathrm{T}_{\text {regs }}$ in the absence of long-term culture or repeated rounds of stimulation.

A previous study utilized a signal peptide deletion construct to show that naive $\mathrm{T}$ cells transfected with an LRRC32 signal peptide deletion construct lacked protein upregulation of CD25, CD62L, and FoxP3 compared to transfection with wildtype LRRC32 [8]. This study utilized GFP-tagged signal peptide deletion constructs that were transfected into HEK293 cells to study the contribution of signal peptide to surface expression of LRRC32 [8]. Surface expression was only evaluated by phase contrast and DAPI confocal microscopy of single cells. These images suggested that some of the LRRC32 signal traffic to the cell surface, in contrast with our prediction. Because experiments by Wang et al. were unclear and did not conclusively show that deletion of the signal peptide region affects cell surface expression of conformationally intact native LRRC32 using antibodies capable of recognizing the extracellular domain of LRRC32, we decided to characterize the functional and phenotypic properties of $\mathrm{T}_{\text {regs }}$ expressing LRRC32 by immunuohistochemistry.

We show that LRRC32 is a marker for a more potent subset of freshly isolated activated $\mathrm{T}_{\text {regs. }}$. We further characterize $T_{\text {reg }}$ subsets with respect to the expression of other $\mathrm{T}_{\text {reg }}$ markers in the context of LRRC32 expression. We examine the intracellular processing of LRRC32 and conclusively demonstrate in multiple cells that the N-terminal portion of LRRC32 is cleaved prior to expression of the protein on the cell surface and that cleavage of this signal peptide is necessary for translocation of the mature protein to the cell surface. Furthermore, we directly confirm, using antibodies specific for native LRRC32, that the signal peptide region of LRRC32 is critical for its surface expression. We also demonstrate low levels of intracellular LRRC32 prior to activation via the $\mathrm{T}$ cell receptor (TCR) and CD28, suggesting that low levels of LRRC32 are sequestered intracellularly and that $\mathrm{T}$ cell activation is necessary for the synthesis and surface expression of LRRC32. Expression of LRRC32 may enhance $\mathrm{T}_{\text {reg }}$ function. Therefore, refinement of immunotherapeutic strategies aimed at targeting LRRC32 may improve strategies for $\mathrm{T}_{\text {reg }}$ isolation and yield more potent $\mathrm{T}_{\text {regs }}$.

\section{Methods}

\section{Isolation of $\mathrm{CD}^{+}$cells}

Peripheral blood was donated by healthy human volunteers coordinated by the Skin Diseases Research Center at University Hospitals Case Medical Center. Signed 
informed consents were obtained from volunteers prior to their participation in the study. The study protocol was approved by the Institutional Review Board of University Hospitals Case Medical Center. Peripheral blood mononuclear cells (PBMCs) were prepared by Histopaque-1077 (Sigma-Aldrich) density gradient separation in accordance with manufacturer's protocols. Negatively selected $\mathrm{CD}^{+}{ }^{+} \mathrm{T}$ cells were purified using magnetic bead technology, per manufacturer's instructions (Miltenyi Biotec).

\section{Generation of Constructs}

Plasmid DNA encoding the cDNA of full length human LRRC32 protein (TrueClone pCMV6-XL6 Human FullLength cDNA Clones, OriGene) was used to transform competent One Shot Top 10 E. coli (Invitrogen), according to the manufacturer's instructions. Selection of positive clones was performed on kanamycin (Invitrogen) LB agar plates. Plasmids were recovered and purified using a Qiaquick MaxiPrep purification kit (Qiagen). The following primers encoding regions flanking the entire Lrrc32 sequence were used to amplify the Lrrc32 cDNA sequence via PCR and insert a TOPO cloning site for pENTR/D-TOPO (Invitrogen): pCMV6-LRRC32 reverse (TTAG GCTTTATACTGTTGGTTAAACTT), pCMV6-LRRC32 reverse readthrough (GGCTTTATA CTGTTGGTTAAACTTCTG), and pCMV6-LRRC32 forward (CACCATGAGACCCCAGA TCCTGCT).

The following 1x PCR buffer conditions were used: AccuPrime Pfx 1x reaction buffer (Invitrogen), $10 \mathrm{mM}$ of forward primer, $10 \mathrm{mM}$ of reverse or reverse readthrough primer, $50 \mathrm{ng}$ of template DNA, and 1 unit of AccuPrime Pfx DNA (Invitrogen). PCR conditions were as follow: initial denaturation at $95 \mathrm{C}$ for 2 minutes followed by 36 cyles of denaturation, annealing, and extension at $95 \mathrm{C}, 55 \mathrm{C}$, and $68 \mathrm{C}$ for $15 \mathrm{~s}, 30$, and 2 minutes, respectively, followed by final extension at 68 C for 30 minutes.

PCR products containing the Lrrc32 sequence derived from reactions utilizing either the forward and reverse primers or forward and reverse readthrough primers were then inserted into pENTR/D-TOPO, per the manufacturer's instructions to generate two different respective constructs: pENTR/D-TOPO/C-terminus LRRC32 (containing a stop codon at the end of the LRR32 sequence) and pENTR/D-TOPO/N-terminus LRRC32 (lacking a stop codon at the end of the LRR32 sequence). One Shot Top $10 \mathrm{E}$. coli were transformed as described above, and positive clones were selected using LB Agar plus kanamycin plates. Plasmid DNA was isolated using a Qiaquick MiniPrep (Qiagen) kit, and M13 forward and reverse primers were subsequently used to facilitate sequencing of the inserted PCR products within each of the screened and purified plasmids via the Sequencing Core at Case Western Reserve University. The reported sequence was aligned with the reported cDNA sequence of LRRC32 obtained from OriGene using the Vector NTI (Invitrogen) software system, and sequence alignments were then confirmed prior to further utilization of the LRRC32 sequence-verified plasmids.

LRRC32 sequence-verified pENTR/D-TOPO/N-terminus LRRC32 or pENTR D-TOPO/C-terminus LRRC32 plasmids were then used in a Gateway (Invitrogen) cloning strategy utilizing either the Vivid Colors pcDNA6.2/ N-EmGFP or pcDNA6.2/C-EmGFP (Invitrogen) as destination vectors, per manufacturer's instructions to generate two products, pcDNA6.2 N-terminus LRRC32/CEmGFP and pcDNA6.2 C-terminus LRRC32/N-EmGFP, encoding "C-GFP/LRRC32" and "N-GFP/LRRC32" respect-ively. Products were used to transform One Shot Top 10 E. coli., and selection of positive clones was performed on LB Agar plus ampicillan plates. Purified plasmids derived from expanded clones were screened again using restriction enzyme analysis to confirm expected restriction sites in the sequence.

To generate an Lrrc32 signal peptide deletion construct, we utilized the newly created pcDNA6.2 C-terminus LRRC32/N-EmGFP vector as a template for PCR amplification. The pCMV6-LRRC32 reverse readthrough primer, described above, as well as a newly created pCMV6-LRRC32 $\triangle$ SP primer (CACCATGGCACAACA CCAAGACAAAGT), designed to anneal optimally to bases just distal to the presumed signal peptide cleavage site of LRRC32, were utilized to generate a PCR product containing the Lrrc32 sequence without a putative signal peptide sequence. The PCR product was then inserted into pENTR/D-TOPO, and an identical strategy as that described above was utilized to create a pcDNA6.2 Nterminus LRRC32 $\triangle \mathrm{SP} / \mathrm{C}$-EmGFP product coding for a LRRC32 signal peptide deletion construct ("C-GFP/ LRRC32 $\Delta$ SP") tagged at the C-terminus end with GFP. The primer "C-EmGFP TOPO Internal Rev" (TGAACTTCAGGGTCAGCTTGCCGTA) was utilized to confirm that the GFP and LRRC32 (minus the signal peptide) coding regions were in frame.

\section{Realtime PCR Analysis}

RNA was extracted using the RNeasy kit (Qiagen). 100 ng of total RNA was then processed using the SuperScript III First-Strand Synthesis System (Invitrogen) and random hexamers as primers and to generate cDNA, per manufacturer's protocol. The following gene expression assays were subsequently used for RT-PCR analysis: FoxP3 (HS00203958_ml, Applied Biosystems), LRRC32 (HS00194136_ml, Applied Biosystems), 18S (HS999 99901_sl, Applied Biosystems), and GFP (Applied Biosystems). RT-PCR analysis was performed in accordance 
with the manufacturer's suggested protocol (Applied Biosystems) with an Applied Biosystems 7500 Realtime PCR system, and StepOne 2.0 analysis software was used to analyze the data.

\section{Transfection of and Establishment of Stable Cell Lines}

HEK293 cells (ATCC, Manassas, VA) were transfected with plasmid containing either pENTR D-TOPO/C-terminus LRRC32 ("C-GFP/LRRC32") or N-terminus LRRC32 ("N-GFP/LRRC32"), utilizing a 3:1 ratio of FuGene 6 (microliters, Roche) to plasmid (micrograms) according to the manufacturer's protocol. Stable transfectants were selected using blastocidin (Invitrogen) according to the manufacturer's protocol, and individual cells were sorted based upon their GFP expression using a FACS Aria cell sorting system (Becton Dickinson) into 96 well plates. Stable clones expressing N-GFP/LRRC32, C-GFP/LRRC32, or C-GFP/LRRC32 $\triangle \mathrm{SP}$ were thus derived from sorted single cells with the highest GFP expression.

\section{Biotinylation of cell surface proteins, Immunoprecipitation and Western Blotting}

Sulfo-NHS-LC-Biotin (\#21327, Pierce) was utilized to label cell surface proteins, in accordance with the manufacturer's protocol. Biotinylated cells were lysed in Glo Lysis Buffer (\#E266A, Promega) per manufacturer protocols. GFP-tagged proteins derived from the cell lysates were then immunoprecipitated with mouse anti-GFP (\#A11120, Invitrogen) using an ExactaCruz E system, per manufacturer's instructions (\#sc-45042, Santa Cruz Biotechnology). Immunoprecipitated proteins were electrophoresed on precast NuPAGE gels (Invitrogen) with their corresponding premade MOPS SDS buffers (Invitrogen). Proteins were transferred to polyvinylidene difluoride (PVDF) membranes (\#LC2002, Invitrogen), per manufacturer's protocol, for subsequent probing using anti-GFP antibody (\#A11121, Invitrogen; \#332600, Zymed) or isotype control antibody (Invitrogen). A SuperSignal PICO (Pierce) kit containing HRPcoupled rabbit anti-mouse antibody was used for detection of GFP-tagged proteins. HRP-coupled goat polyclonal to mouse IgG (\#ab6789, Abcam) was also used to recognize bound murine antibody. Rabbit polyclonal antibodies to Foxp3 (\#ab10563, Abcam) were used to probe for human FoxP3 on membranes, and HRPcoupled goat polyclonal antibodies to rabbit IgG were used to recognize bound rabbit antibodies. For detection of biotinylated proteins, streptavidin-HRP (\#21126, Pierce) was utilized.

For the assessment of cellular LRRC32 expression in the context of the signal peptide deletion constructs, an identical protocol as above was used except that cells were lysed using the M-PER Mammalian Protein
Extraction Reagent (\#78503, Pierce). Plato-1(ALX-804867-C100, Axxora) was used to detect LRRC32, and the Pierce Fast Western Blot Kit (\#35050, Pierce) was used to visualize immunoblots.

\section{Flow Cytometry Analysis of $\mathrm{CD} 4^{+}$Cells}

$\mathrm{CD} 4^{+}$cells were placed in culture media (RPMI, 10\% FBS, penicillin, streptomycin, L-glutamine, and $\beta$-mercaptoethanol) and rested overnight in 96-well plates or stimulated in anti-CD3-coated plates supplemented with soluble murine anti-human CD28 (1 microgram/ml, Becton Dickenson) [23]. Cells were subsequently stained using antibodies to CD25 (clone 2A3, Becton Dickenson), LRRC32 (Axxora), FoxP3 (eBioscience), and a panel of antibodies specific for CD69 (Becton Dickinson), CD62L (Becton Dickinson), GITR (R \& D Biosystems), CTLA4 (Becton Dickinson), HLA-DR (Becton Dickinson), and CD45RO (Becton Dickinson), per manufacturer's protocol for staining cells for flow cytometry (eBioscience). Cells were fixed and then permeabilized using a fixation permeabilization kit (eBioscience) after staining surface antigens in order to study the intracellular expression of certain proteins (LRRC32, FoxP3). For assessment of intracellular expression of LRRC32, permeabilized cells were incubated with 2.5 micrograms $/ \mathrm{ml}$ of IgG2b control isotype antibody (Invitrogen) for 30 minutes prior to incubation with labeled antiLRRC32 antibody to decrease non-specific binding. Isotype controls were performed for compensation. Cells were analyzed on a Becton Dickenson LSR II flow cytometer. In all instances, with the exception of the mRNA studies, CD25 $5^{\text {hi }}$ cells represented the top $5 \%$ of $\mathrm{CD} 25^{+}$cells. In the case of the mRNA studies in which $\mathrm{CD} 25^{\mathrm{hi}}$ and ${ }^{\mathrm{mid}}$ populations were identified, CD $25^{\mathrm{hi}++}$ cells represented the top $1.5 \%$ of $\mathrm{CD} 25^{+}$cells, and CD $25^{\text {hi+ }}$ cells represented the next highest $2-3 \%$ of $\mathrm{CD} 25^{+}$cells as depicted in Figure 1a.

\section{Expansion and stimulation of $\mathrm{T}_{\text {regs }}$}

$\mathrm{CD} 4^{+}$cells were isolated as described above. Subsequently, the cells were stained with anti-CD25 (Becton Dickenson). The top $5 \%$ of CD $25^{\text {hi }}$ cells were sorted, and cells were expanded and stimulated for 2 weeks using beads coated with anti-CD3 and anti-CD28 according to manufacturer directions (Dynabeads Human $\mathrm{T}_{\text {reg }}$ Expander, Catalog \#111.29, Invitrogen) prior to characterization. Unstimulated sorted CD25 $5^{\text {hi }}$ cells derived from isolated $\mathrm{CD} 4^{+}$cells from the same patient were used as a control for unsimulated $\mathrm{T}_{\text {regs. }}$.

\section{Proliferation Assay}

Negatively selected $\mathrm{CD} 4^{+}$cells were stained with antiCD25, and the top $5 \%$ of CD25 cells $\left(C D 25^{\text {hi }}\right)$ were sorted using a Becton Dickenson FACS Aria cell sorter. 


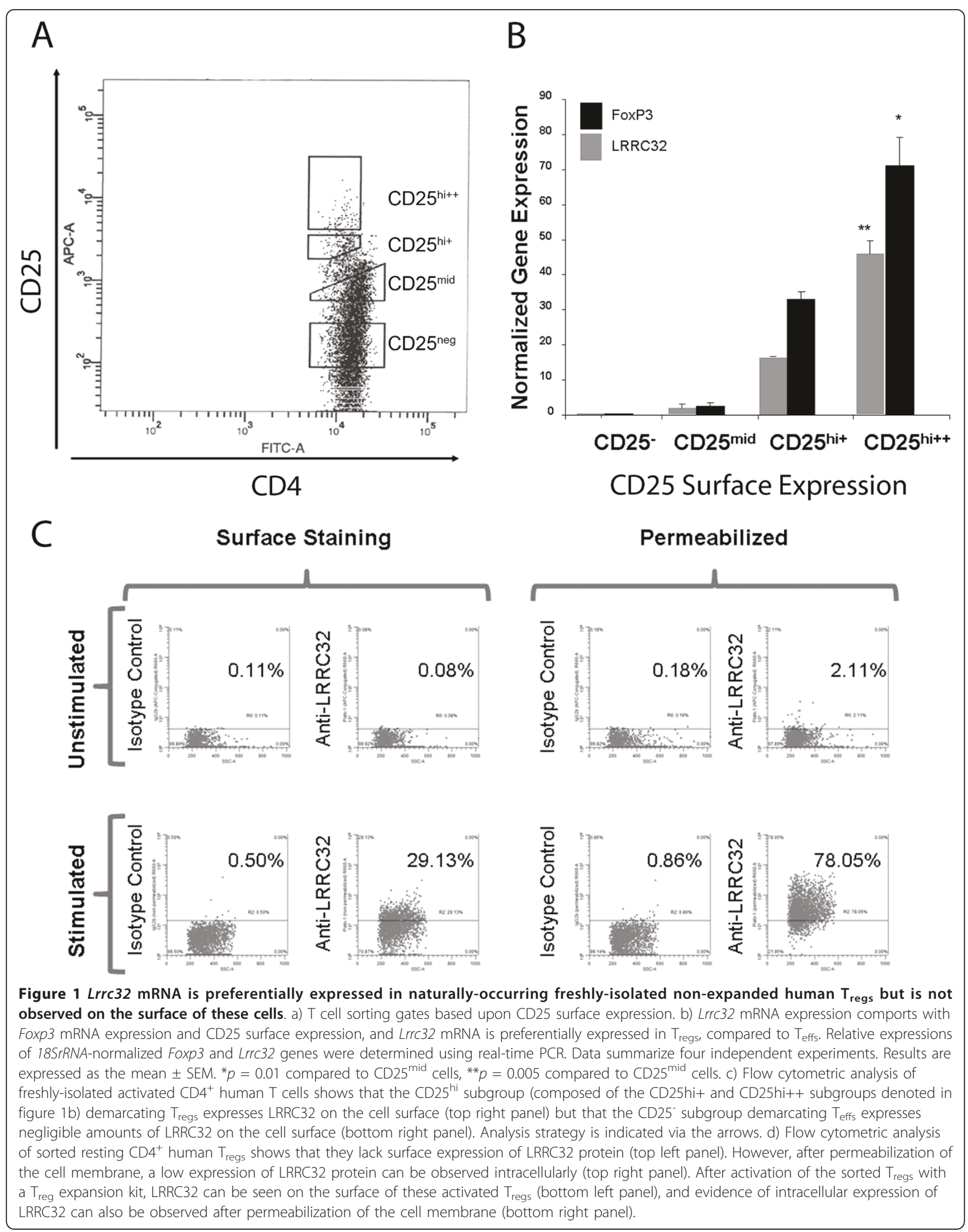


Isolated cells were stimulated overnight on anti-CD3coated plates (Becton Dickinson) supplemented with soluble murine anti-human CD28 (Pharmingen) as described above. CD25 effector T cells were maintained in culture media. Stimulated CD $25^{\text {hi }}$ cells were subsequently stained with antibody specific for LRRC32 (Axxora), and LRRC32 ${ }^{+}$and LRRC32 subpopulations were further sorted. LRRC $32^{+}$positive and LRRC32 $\mathrm{T}_{\text {reg }}$ subpopulations were then co-cultured with CD25 effector $\mathrm{T}$ cells plus irradiated allogeneic antigen presenting cells (APCs) at various $\mathrm{T}_{\text {reg: }}: \mathrm{T}_{\text {eff }}$ ratios ranging from 1:1 to 1:16 in a 96 well round bottomed tissue culture plate (Costar) as previously described [23]. Each well contained 20,000 $\mathrm{T}_{\text {effs }}$ and 50,000 APCs which had been previously irradiated at 3,000 Rad. Mixed lymphocytes were cultured for 6 days, and cells were pulsed with $1 \mu \mathrm{Ci} /$ well $\left[{ }^{3} \mathrm{H}\right]$ thymidine (NET-027A, PerkinElmer) for the last $16 \mathrm{~h}$. Proliferation was measured using a TopCount scintillation counter (Perkin-Elmer). Maximum proliferation was calculated by measuring the proliferation of cells in wells lacking $\mathrm{T}_{\text {regs }}$ and containing only $\mathrm{T}_{\text {effs }}$ and APCs. Background proliferation was ascertained via measurement of proliferation of $\mathrm{T}_{\text {effs }}$ only in the absence of APCs.

\section{Statistical Analysis}

Statistical analysis was performed using Student's t test (surface phenotype analysis) or a three way ANOVA (mixed lymphocyte response assays) as indicated in the figure legends. A value of $p=0.05$ was considered significant, unless otherwise indicated.

For the ANOVA, the overall $p$ value reported is reflective of the difference between the average proliferation of $\mathrm{T}_{\text {regs }}$ using LRRC32 as an independent variable while controlling for the individual assays as well as the titration. The $R^{2}$ value represents the amount of variability in the ANOVA analysis that is accounted for by the presence or absence of LRRC32 on the surface of a $\mathrm{T}_{\text {reg }}$, the individual assays, as well as the titration.

\section{Results}

\section{Lrrc32 Is Preferentially Expressed in $\mathrm{T}_{\text {regs }}$}

A preliminary microarray analysis demonstrated upregulated $\operatorname{Lrrc32}$ gene expression in $\mathrm{T}_{\text {regs }}$ [9]. To confirm these findings, we performed RT PCR analysis examining LRRC32 mRNA expression in sorted subpopulations of CD25-expressing cells as depicted (Figure 1a) representing $1.5 \%$ of the $\mathrm{CD} 44^{+}$cell population with the highest expression of CD25 $\left(\mathrm{CD} 25^{\mathrm{hi+}+}\right), 2-3 \%$ of the $\mathrm{CD} 4{ }^{+}$ cell population with high expression of CD25 $\left(\mathrm{CD} 25^{\mathrm{hi}+}\right)$, $17-20 \%$ of the $\mathrm{CD} 4^{+}$cell population with reduced expression of CD25 (CD25 ${ }^{\text {mid }}$ ), or no expression of CD25 (CD25 ). These analyses revealed that $2 r r c 32$ expression increased with surface CD25 expression in a manner similar to Foxp3 expression (Figure 1b), confirming that $\operatorname{Lrrc32}$ is preferentially expressed in $\mathrm{T}_{\text {regs }}$. To confirm that LRRC32 is specifically upregulated in activated $\mathrm{T}_{\text {regs }}$, we compared the surface expression of LRRC32 in the CD25 hi population and the CD25 $\mathrm{T}_{\text {eff }}$ population of $\mathrm{CD} 4^{+}$cells stimulated overnight with plate bound anti-CD3 and soluble anti-CD28 and found that LRRC32 is preferentially expressed on the surface of activated $\mathrm{T}_{\text {regs }}$ but not activated $\mathrm{T}_{\text {effs }}$ (Figure 1c), in accordance with a previous study [10]. Furthermore, in accordance with this previous study, we also confirmed that surface LRRC32 is present on sorted $\mathrm{CD} 44^{+} \mathrm{CD} 25^{\mathrm{hi}}$ $\mathrm{T}_{\text {regs }}$ representing $5 \%$ of the $\mathrm{CD} 4^{+}$cell population with the highest expression of CD25 (i.e. including both the $\mathrm{CD} 25^{\mathrm{hi++}}$ and CD25 ${ }^{\mathrm{hi}+}$ subgroups described above, Figure $1 \mathrm{~d}$, surface expression, stimulated, bottom left panel set) that had been activated for 2 weeks with beads coated with anti-CD28 and anti-CD3 but not on unstimulated sorted $\mathrm{CD} 44^{+} \mathrm{CD} 25^{\text {hi }} \mathrm{T}_{\text {regs }}$ (Figure $1 \mathrm{~d}$, surface expression, unstimulated, top left panel set) [10]. A low intracellular expression of LRRC32 in resting sorted $\mathrm{CD} 4{ }^{+} \mathrm{CD} 25^{\text {hi }} \mathrm{T}_{\text {regs }}$ was noted (Figure $1 \mathrm{~d}$, permeabilized expression, unstimulated, top right panel set). This suggests that low levels of LRRC32 may be sequestered in $\mathrm{T}_{\text {regs }}$ or might require additional processing prior to surface expression. Increased expression of LRRC32 could be seen in activated $\mathrm{CD} 4{ }^{+} \mathrm{CD} 25^{\mathrm{hi}}$ sorted Tregs that had been permeabilized (Figure 1d, permeabilized expression, stimulated, bottom right panel set) and was higher than that seen on the surface only (Figure 1d, surface expression, stimulated, bottom left panel set), as would be expected for a surface protein that is initially produced intracellularly upon cell activation before trafficking to the cell surface.

\section{Lrrc32 Is Cleaved After Processing}

Sequence analysis of murine LRRC32 predicted that LRRC32 would be expressed as a transmembrane protein [6]. We analyzed the sequence of human LRRC32 using the transmembrane domain prediction server at Stockholm Bioinformatics Center with a dense alignment method and confirmed the existence of a putative 19 amino acid transmembrane domain incorporating residues 628 through 646 (data not shown), in agreement with prior reports that this protein was expressed at the cell surface $[10,11]$. Using the SignalP 3.0 server, we also identified a putative 17 amino acid signal peptide sequence and cleavage site between residues 17 and 18 (Figure 2a), consistent with the requirement for a signal peptide to be present in a protein destined for expression at the cell surface [24]. To further understand protein processing and surface expression of human LRRC32, we generated LRRC32 constructs incorporating green fluorescent protein (GFP) at either 


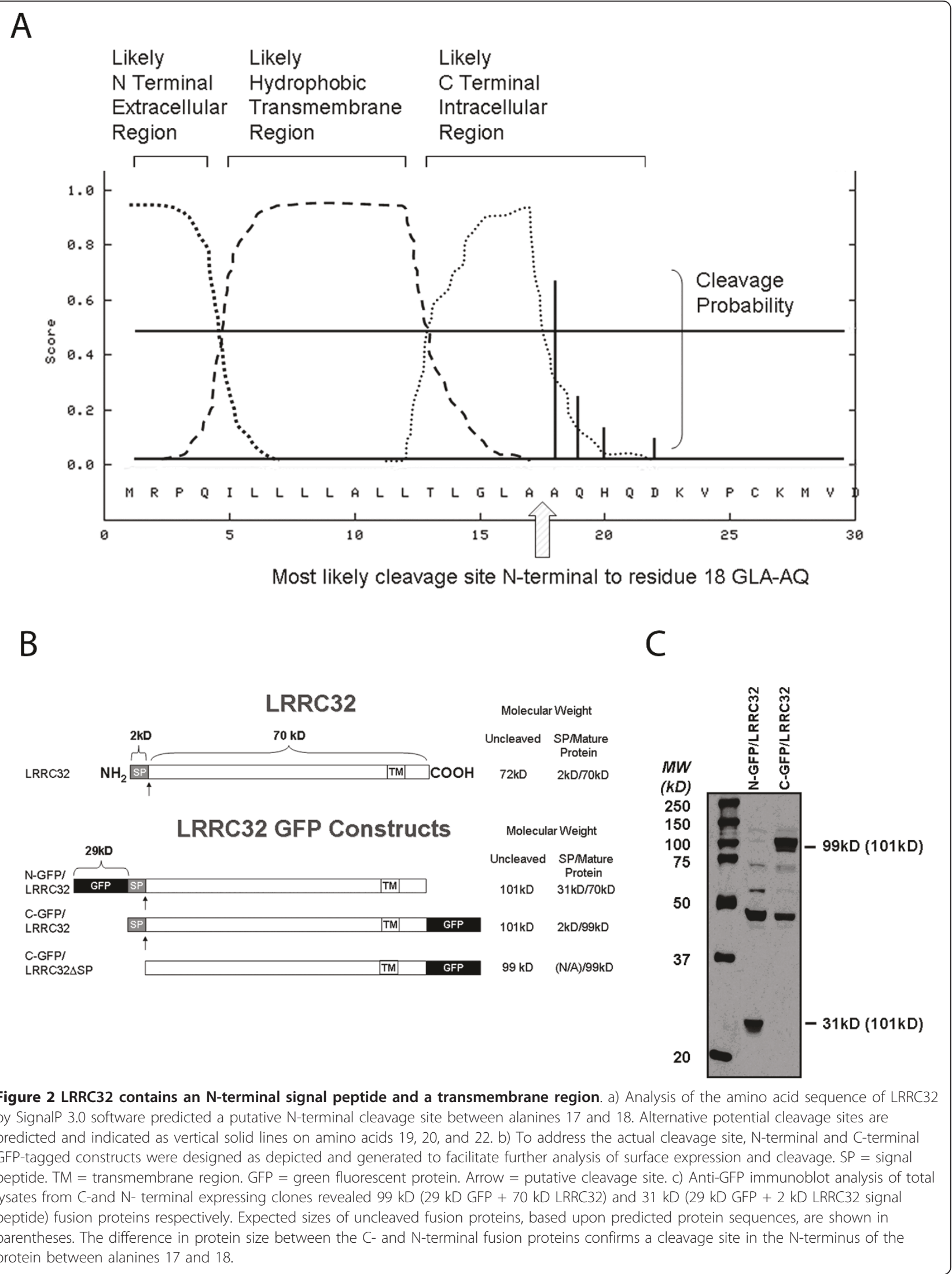


the $\mathrm{N}$ - or $\mathrm{C}$ - terminus, thereby allowing us to examine the tagged signal peptide or the mature protein, respectively (Figure 2b). Using anti-GFP antibodies, we examined total lysates from HEK-transfected C- and Nterminus tagged LRRC32-expressing clones (Figure 2c). Here, we show that $99 \mathrm{kD}(29 \mathrm{kD}$ GFP+70 kD LRRC32) and $31 \mathrm{kD}$ (29 kD GFP+2 kD LRRC32) fusion proteins, respectively, are generated in HEK transfectants overexpressing LRRC32, consistent with a cleaved N-terminus signal peptide generated prior to surface expression of LRRC32.

\section{Lrrc32 on Transfected HEK293 Cells Is Expressed at the Cell Surface Regardless of Stimulation}

Although $\mathrm{T}_{\text {regs }}$ appear to require activation prior to expressing LRRC32 on their surface, the same is not true for transfected cell lines such as HEK293, and the use of the HEK293 cell line allowed us to easily study factors affecting the surface expression of LRRC32 in a system that would not require constant $\mathrm{T}$ cell isolation and activation $[10,11,25]$. We used $\mathrm{C}$ - and $\mathrm{N}$-terminal GFP-tagged LRRC32 (C-GFP/LRRC32 and N-GFP/ LRRC32, respectively) expressing HEK293 cell clones for surface biotinylation and analysis. Following surface biotinylation, cell lysates were prepared and anti-GFP antibodies were used to immunoprecipitate the fusion proteins. Precipitated protein was transferred to a PVDF membrane. The membrane was then probed for biotin using streptavidin-HRP (Figure 3a, left panel) or for GFP using an anti-GFP antibody (Figure 3a, right panel). Our results demonstrate biotinylated surface protein only in C-GFP/LRRC32-expressing clones (Figure 3a, left panel, rightmost lane), consistent with both surface membrane expression of LRRC32 and intracellular $\mathrm{N}$-terminal processing (removal of the GFP-N-terminal signal peptide) prior to membrane localization. Probing the membrane with anti-GFP (Figure 3a, right panel) demonstrates the surface and intracellular portions of LRRC32 after cleavage.

Confocal studies with C-terminal GFP-tagged LRRC32 (C-GFP/LRRC32)-transfected HEK293 cells confirm that GFP expression is found on the cell surface without stimulation, in accordance with predictions that LRRC32 would be found on the cell surface (Figure $3 \mathrm{~b}$, fourth row, right column). In contrast, N-terminal GFP-tagged LRRC32 (N-GFP/LRRC32)-transfected HEK293 cells exhibit GFP expression diffusely within cells, and GFP expression is not concentrated at cell surfaces, presumably since the GFP-tagged cleaved signal peptide of $\mathrm{N}$ GFP/LRRC32 remains intracellularly after cleavage, prior to the translocation of the mature LRRC32 protein to the cell surface (Figure 3b, third row, right column). Antibody staining of surface LRRC32 confirmed that mature C-GFP/LRRC32 and N-GFP/LRRC32 traffic to

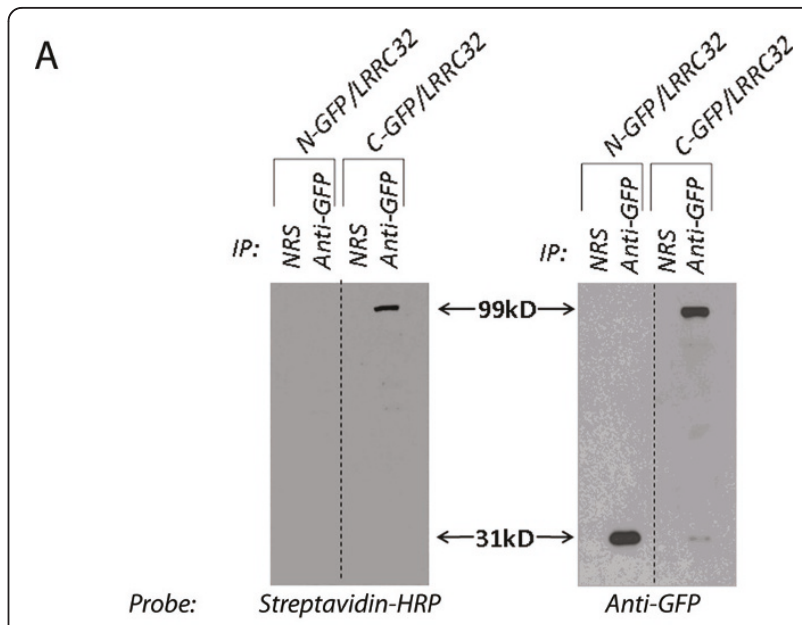

B

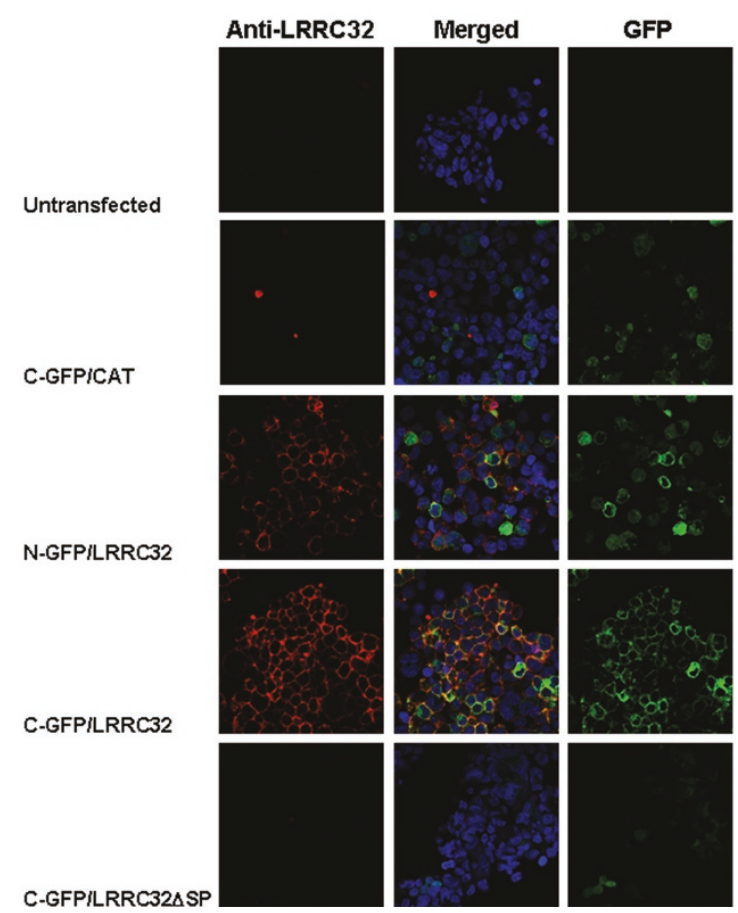

Figure $\mathbf{3}$ LRRC32 is a cell surface protein. a) C-and N-terminus GFP-tagged LRRC32 expressing HEK293 cell clones were surface biotinylated, and cell lysates were immunoprecipitated using antibody specific for GFP or using normal rabbit serum (NRS) as a control (left and right panels). Protein lysates were then electrophoresed, transferred to membrane PDVF, and probed for the presence of biotinylation using streptavidin-HRP (left panel only). Blots were also probed with anti-GFP (right panel only). b) Confocal analysis of untransfected (top row) HEK293 cells, C-GFP/ CAT-transfected HEK293 cells (second row), N-GFP/LRRC32transfected HEK293 cells (third row), C-GFP/LRRC32-transfected HEK293 cells (fourth row), and C-GFP/LRRC32 $\triangle$ SP-transfected HEK293 cells (last row); Green $=$ GFP, Red $=$ anti-LRRC32 antibody, Blue $=$ nuclear counterstain. The left column shows anti-LRRC32 only. The right column shows GFP only. The middle column shows the merged composite confocal picture (anti-LRRC32 + GFP) with the nuclear counterstain. 
the cell surface (Figure 3b, third and fourth rows, left column). Our untransfected control cell line did not express GFP or LRRC32 staining, as expected (Figure 3b, top row). Furthermore, our C-terminal GFP-tagged chloramphenicol acetyltransferase (C-GFP/CAT) control cell line did not express LRRC32 staining, as expected (Figure 3b, second row).

\section{A putative signal peptide region corresponding to the first 17 amino acids of Lrrc32 is required for surface protein expression of Lrrc32}

Since signal peptides are generally necessary to direct surface expression of proteins, we next decided to see whether deletion of the putative signal peptide region would inhibit surface expression of LRRC32 [26-28]. HEK293 cells transfected with a C-terminus GFP-tagged LRRC32 construct lacking the signal peptide (C-GFP/ LRRC32 $\triangle$ SP) did not express surface LRRC32 by confocal microscopy (Figure 3b, bottom row). Furthermore, they did not express surface LRRC32 by flow cytometry but were GFP positive, compared to HEK293 cells transfected with the full length C-terminus GFP-tagged LRRC32 construct, expressing both GFP and surface LRRC32 (Figure 4a). Control untransfected cells did not express GFP or surface LRRC32, as expected (Figure 4a, leftmost panel).

Given the absence of surface expression of LRRC32 in cells transfected with C-GFP/LRRC32 $\triangle \mathrm{SP}$, we concluded that the signal peptide portion of LRRC32 was critical for surface expression of LRRC32. It was unclear, however, whether the absence of surface expression of LRRC32 was due to intracellular sequestration of LRRC32. We therefore conducted a western blot analysis of lysates from HEK293 cells transfected with our various constructs using an anti-LRRC32 antibody. Our results showed that while LRRC32 can be detected in cell lysates from cells transfected with full-length LRRC32 constructs (C-GFP/LRRC32 and N-GFP/ LRRC32 at 99 and $70 \mathrm{kD}$, respectively), LRRC32 could not be detected in cell lysates of HEK293 cells transfected with the C-GFP/LRRC32 $\triangle \mathrm{SP}$, suggesting that LRRC32 is either produced at levels that were undetectable or is rapidly broken down following translation (Figure 4b).

To confirm that Lrrc32 was being transcribed, we utilized RT-PCR to analyze mRNA from lysates of HEK293 cells transfected with our various constructs. Our analysis showed that Lrrc32 mRNA was detected in the CGFP/LRRC32 as well as the C-GFP/LRRC32 $\triangle$ SP-transfected HEK293 cell lysates (Figure 4c, left panel). In contrast, untransfected HEK293 cells as well as the control C-terminus tagged chloramphenicol acetyltransferase (C-CAT)-transfected HEK293 cell lysates had undetectable levels of Lrrc32 mRNA. Furthermore, as expected, GFP expression was observed in all of the HEK293 transfected cells examined (Figure 4c, right panel). As we utilized stable clones derived from sorted single cells with the highest GFP expression, as described above, the different efficiencies of C-GFP/ LRRC32 vs. C-GFP/LRRC32 $\triangle$ SP may be due to differential stability/integration of the plasmids in the selected clones. Furthermore, it is possible that the signal peptide mutant may be less stable, and as a result, cells transfected with GFP/LRRC32 $\triangle$ SP may compensate by producing more mRNA to produce more protein.

\section{Characterization of $\mathrm{CD} 62 \mathrm{~L}$ expression and functional status of $\mathrm{LrrC}^{+} 2^{+}$and LrrC32- naturally-occurring freshly isolated human $T_{\text {regs }}$}

Using polyclonal activation via the TCR in combination with anti-CD28 co-stimulation, we confirmed that LRRC32 is expressed on the surface of naturally-occurring freshly-isolated activated $\mathrm{T}_{\text {regs }}$ compared to unstimulated $\mathrm{T}_{\text {regs }}(24.02 \% \pm 1.73 \%(\mathrm{n}=6)$ vs. $2.30 \% \pm$ $1.05 \%(\mathrm{n}=6)$, data not shown), respectively. We subsequently confirmed that surface LAP expression is also observed in this cell population following activation with plate-bound anti-CD3 and soluble anti-CD28, in agreement with a recently published report (Figure $5 \mathrm{a}$ ) [11].

To date, no single surface marker is sufficient for identifying naturally-occurring $\mathrm{T}_{\text {regs. }}$. In order to address the expression of LRRC32 in the context of previously described surface markers, we analyzed LRRC $32^{+}$and LRRC32- subsets of CD $4^{+} \mathrm{CD} 25^{\text {hi }}{ }^{-}$oxP $3{ }^{+}$LRRC $32^{+} \mathrm{T}_{\text {regs }}$, as well as unactivated $\mathrm{T}_{\text {regs }}$, with respect to the surface co-expression of CD62L, CD45RO, CD69, GITR, CTLA4, and HLA-DR (Figures 5b and 5c). Stimulated $\mathrm{T}_{\text {regs }}$ demonstrated expected increases in the surface expression of GITR, CD69, and CTLA4. Of interest, however, stimulated LRRC $32^{+} \mathrm{T}_{\text {regs }}$ exhibited less CD62L and CD45RO than resting and stimulated LRRC32- $\mathrm{T}_{\text {regs }}$, suggesting that LRRC $32^{+} \mathrm{T}_{\text {regs }}$ may represent a subset of activated or differentiated $\mathrm{T}_{\text {regs }}$.

To address whether or not functional differences in ${\text { LRRC } 32^{+} \text {and LRRC32 }}^{-}$subsets of naturally-occurring freshly isolated $\mathrm{T}_{\text {regs }}$ exist, we examined the suppressive capacity of LRRC32 $2^{+}$and LRRC32- $\mathrm{T}_{\text {regs }}$. Given previous reports that transfection of Lrrc32-bearing constructs into "pre-regulatory $\mathrm{T}$ cells" could induce them to upregulate FoxP3 expression, we hypothesized that the LRRC $32^{+}$subset of naturally-occurring freshly-isolated $\mathrm{CD} 4{ }^{+} \mathrm{CD} 25^{\text {hi }} \mathrm{T}_{\text {regs }}$ would be more suppressive than the LRRC32- subset of $\mathrm{CD} 4^{+} \mathrm{CD} 25^{\text {hi }} \mathrm{T}_{\text {regs }}$ [8]. As described above, our data demonstrates that LRRC32 expression comports with FoxP3 ${ }^{+}$expression. Therefore, we first sorted $\mathrm{CD} 25^{\mathrm{hi}} \mathrm{CD} 4^{+}$-purified cells and then activated these and sorted again for $\mathrm{T}_{\text {regs }}$ expressing surface 
A

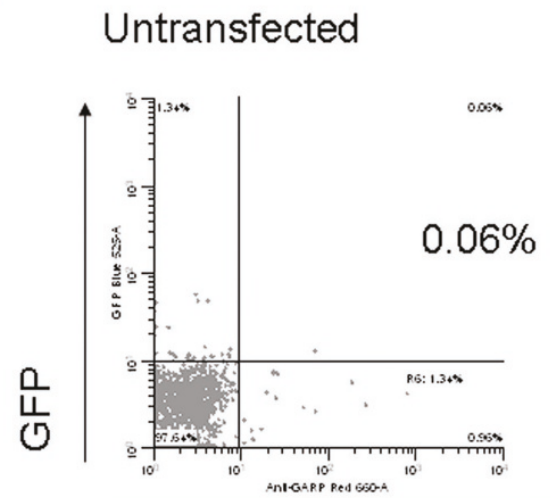

C-GFP/LRRC32

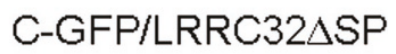

C-GFP/LRRC32 $\triangle S P$
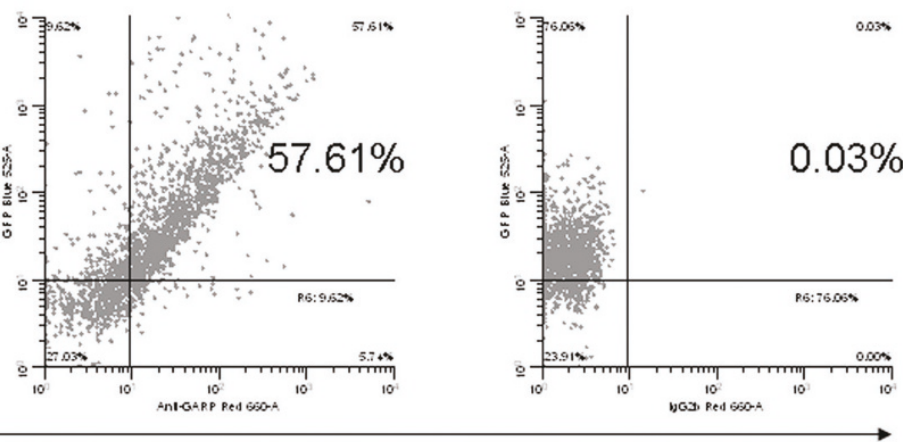

\section{LRRC32}

B

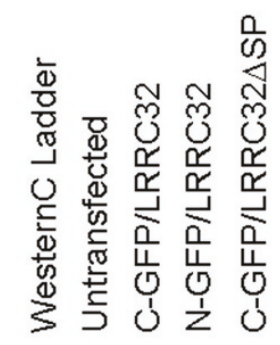

$C$
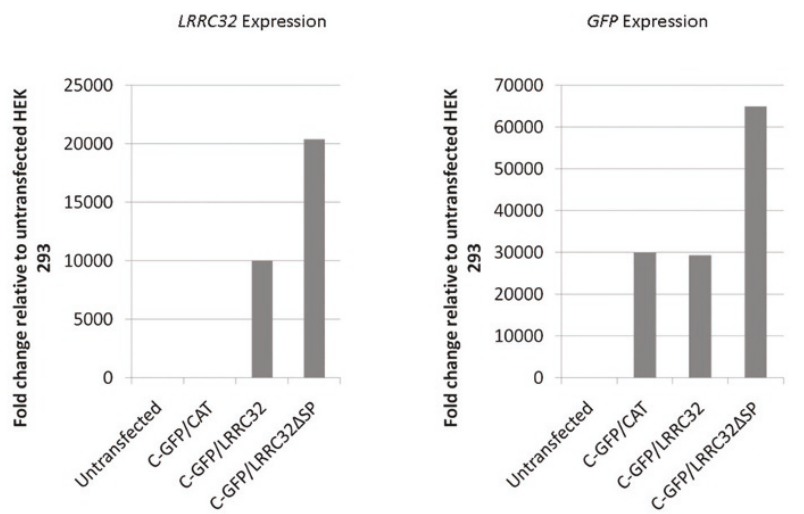

C-GFP/LRRC32

(99kD)

$\mathrm{N}-\mathrm{GFP} / \mathrm{LRRC} 32$

(70 kD)

50

37

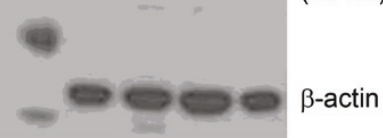

Figure 4 A 17 AA signal peptide is required for the cell surface expression of LRRC32. a) Untransfected HEK293 cells or cells transfected with either C-terminus GFP-tagged LRRC32 or C-terminus GFP-tagged LRRC32 with a deleted signal peptide region were analyzed by flow cytometry for surface expression of LRRC32 or GFP expression. b) Anti-LRRC32 immunoblot analysis of total lysates from C-and N- terminus GFPtagged LRRC32 expressing clones revealed intact LRRC32 expression at 99 kD (fusion protein: 29 kD GFP + 70 kD LRRC32) and 70 kD,

respectively. However, immunoblot analysis of total lysates from C-terminus GFP-tagged LRRC32 expressing clones lacking an intact signal peptide did not detect the presence of LRRC32 (rightmost lane). c) RT-PCR analysis of HEK293 cell lysates utilizing untransfected, C-CAT, Cterminus GFP-tagged LRRC32, or C-terminus GFP-tagged LRRC32 lacking an intact signal peptide was performed using primers for Lrrc32 (left panel) or GFP (right panel).

LRRC32. Isolated LRRC32 ${ }^{+}$or LRRC32- $\mathrm{T}_{\text {regs }}$ were then used in mixed lymphocyte response assays to assess the relative suppressive capabilities of each isolated population of $\mathrm{T}_{\text {regs. }}$. Our results confirmed that naturally-occurring freshly-isolated LRRC $32^{+} \mathrm{T}_{\text {regs }}$ are more suppressive than LRRC32- $\mathrm{T}_{\text {regs }}$ (Figure 5d), exhibiting significant increases in suppression at $\mathrm{T}_{\text {reg: }}: \mathrm{T}_{\text {eff }}$ ratios of 1:4, 1:8, and 1:16 ( $p=0.0324,0.0142$, and 0.0430 , respectively).

\section{Discussion}

The isolation of naturally-occurring functional $\mathrm{T}_{\text {regs }}$ will be a prerequisite for successful adoptive immunotherapy 
A

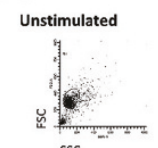

ssc

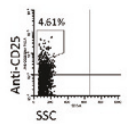

mulated
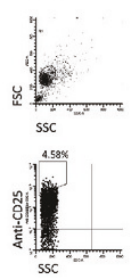

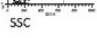
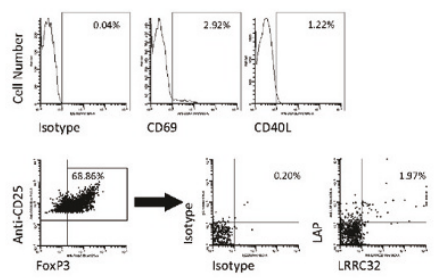

B
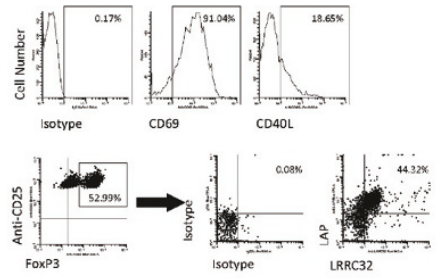

Stimulated $\mathrm{CD}^{+}{ }^{+} \mathrm{CD} 25^{\text {hi }} \mathrm{FoxP}^{+} \mathrm{T}_{\text {regs }}$
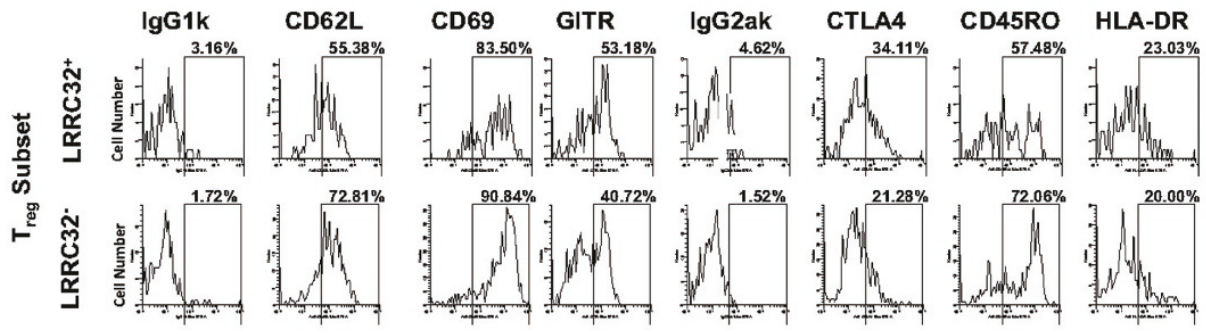

\section{Unstimulated $\mathrm{CD} 4^{+} \mathrm{CD} 25^{\text {hi }} \mathrm{FoxP}^{+} \mathrm{T}_{\text {regs }}$}
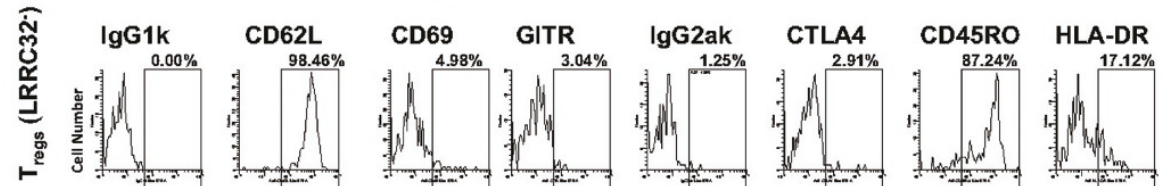

Figure 5 LRRC32 $2^{+} \mathrm{CD} 4^{+} \mathrm{CD} 25^{\mathrm{hi}}$ FoxP3 $\mathrm{T}_{\text {regs }}$ appear to be more potent suppressors than LRRC32 $2^{-} \mathrm{CD} 4^{+} \mathrm{CD} 25^{\mathrm{hi}}$ FoxP3 and exhibit decreased CD62L upon activation. a) Expression of LRRC32 and LAP in CD4+ T cells rested overnight (top panel) or stimulated with plate bound anti-CD3 and soluble anti-CD28 (bottom panel). $T_{\text {regs }}$ were selected from the top 5\% CD25-expressing and FoxP3 ${ }^{+}$populations, as previously described. Confirmation of activation by expression of the surface markers CD40L and CD69 are also shown (top of each panel). b) The expression patterns of various $\mathrm{T}_{\text {reg }}$ and activation surface markers (CD62L, CD69, GITR, CTLA4, CD45RO, and HLA-DR) in FoxP3 ${ }^{+}$and LRRC32 ${ }^{+}$-gated populations of CD25 ${ }^{\text {hi }}$ cells were studied using flow cytometry. Stimulated $\mathrm{CD} 4^{+} \mathrm{FoxP} 3^{+} \mathrm{CD} 25^{\text {hi }} \mathrm{T}_{\text {regs }}$ (top panel) \& unstimulated $\mathrm{CD} 4^{+} \mathrm{FoxP}^{+} \mathrm{CD} 25^{\text {hi }} \mathrm{T}_{\text {regs }}$ (bottom panel). $\mathrm{C}$ ) Composite summary of phenotypic analysis of unstimulated LRRC32 CD4 $4^{+} \mathrm{CD} 25^{\text {hi }} \mathrm{FOXP3} 3^{+} \mathrm{T}_{\text {regs }}$ and stimulated LRRC32 $2^{+}$and LRRC32 CD4

${ }^{+}$CD25 ${ }^{\text {hi }}$ FoxP3 $^{+} \mathrm{T}_{\text {regs }}$. Black bars $=$ unstimulated LRRC32- $\mathrm{T}_{\text {regs. }}$. Dark grey bars = stimulated LRRC32- $\mathrm{T}_{\text {regs. }}$. Light grey bars $=$ stimulated $L R R C 32^{+} \mathrm{T}_{\text {regs }}$. Data are expressed as the mean \pm SEM from 3 individuals. Heteroscedastic variances and an independent t-test comparing stimulated LRRC32 $2^{+}$and LRRC32 subsets were used for calculations of the $p$ values which are reported along the x-axis, below each surface marker $\left({ }^{*}\right)$. d) CD25 hi cells were sorted and activated overnight using anti-CD3-coated plates and soluble anti-CD28 (1 microgram/ml). Cells were then resorted based upon LRRC32 expression. The suppressive capacities of these $L R R C 32^{+}$and $L R R C 32^{-} T_{\text {regs }}$ were subsequently tested in a mixed lymphocyte reaction utilizing syngeneic effectors ( $T_{\text {eff }}, 20,000 /$ well) and allogenic antigen presenting cells (50,000/well). $T_{\text {reg }}: T_{\text {eff }}$ ratios are depicted above. Data summarize 3 independent experiments. Results are expressed as the mean \pm SEM. $p=0.0001$ and $R^{2}=0.7244$. Absolute proliferation values for the 3

experiments were as follow: $T_{\text {effs }}$ alone: average of $31094 \mathrm{cpm}$ to average of $47483 \mathrm{cpm}$ (at least 6 replicates per assay), background: average of 24 $\mathrm{cpm}$ to $35 \mathrm{cpm}$ (at least 6 replicates per assay); $T_{\text {reg }}: T_{\text {eff }}$ ratio of 1:1: $89 \mathrm{cpm}$ to $346 \mathrm{cpm}$. When titrating $T_{\text {regs }} v \mathrm{vs}$. $T_{\text {effs, }} 3$ replicates were performed at each titration for the LRRC32 ${ }^{+}$and $L R R C 32^{-} T_{\text {regs }}$ except for in one assay set in which there was limited number of $L R R C 32^{+} T_{\text {regs. }}$ In this case, only one replicate was performed at the 1:1 and 1:2 titrations, and two replicates were performed for the other titrations $(0: 1,1: 4,1: 8$, and 1:16). We performed 3 replicates for each titration utilizing the LRRC32- $\mathrm{T}_{\text {regs. }}$ 
techniques in humans. Murine adoptive immunotherapy models have demonstrated proof of concept that isolated $\mathrm{T}_{\text {regs }}$ can be used as therapy for several autoimmune disorders [29-31]. The isolation of functional $\mathrm{T}_{\text {regs }}$ in humans, however, is problematic, in part due to a paucity of specific surface markers. In this report, we demonstrate direct evidence of the surface expression of LRRC32 on freshly-isolated, naturally-occurring, and non-expanded CD4+CD25 hi human $\mathrm{T}_{\text {regs }}$ following TCR activation. We furthermore have characterized LRRC32 processing and demonstrate that sorted subsets of freshly isolated $\mathrm{T}_{\text {regs }}$ bearing this marker appear more suppressive than subsets lacking this marker.

Previous studies have shown that constitutive overexpression of Lrrc32 in CD25- $\mathrm{T}_{\text {effs }}$ can lead to Foxp3 upregulation and that these cells subsequently acquire a suppressive phenotype $[8,25]$. Similarly, overexpression of Foxp3 has been shown to result in increased mRNA levels of Lrrc32, suggesting positive feedback between FoxP3 and LRRC32 $[8,25]$. Although other groups have shown that surface LRRC32 is highly elevated in expanded activated $\mathrm{T}_{\text {regs }}$ compared to CD25 $\mathrm{T}_{\text {effs }}$, we demonstrate here that low levels of intracellular LRRC32 are detectable in naturally-occurring freshlyisolated unstimulated $\mathrm{T}_{\text {regs }}$ (Figure 1d) [8,25].

Previous studies utilizing an antibody generated against amino acids 296-308 of LRRC32 failed to detect LRRC32 on transfected Jurkat cells or on native CD4 ${ }^{+} \mathrm{CD} 25^{\mathrm{hi}} \mathrm{T}_{\text {regs }}$ [25]. However, as shown here, a commercially available anti-LRRC32 monoclonal antibody does recognize surface LRRC32 on transfected HEKs and naturally-occuring freshly-derived $\mathrm{T}_{\text {regs }}$ that have undergone stimulation. Furthermore, it detects low intracellular expression of LRRC32 in naturally-occurring freshlyderived $\mathrm{T}_{\text {regs. }}$. Failure to detect surface LRRC32 by the antibody raised against peptide 296-308 may be due to competitive occupation by a ligand as this region of LRRC32 corresponds to a loop and has been hypothesized to correspond to a ligand binding site [25]. One proposed ligand that could occupy this site may be LAP, as recently published work has demonstrated an interaction between LAP and LRRC32 [11,13,32]. If residues 296-308 of LRRC32 act as a binding site for LAP, occupation of this site may account for the failure of previous LRRC32-specific antibodies to recognize surface LRRC32 expression.

To determine if LRRC32 is sequestered in $\mathrm{T}_{\text {regs }}$, we examined the intracellular expression of LRRC32 in naturally-occurring freshly-isolated unstimulated $\mathrm{T}_{\text {regs }}$ by flow cytometry. We show that unstimulated $\mathrm{T}_{\text {regs }}$ contain low levels of intracellular LRRC32 protein. However, coupled with our RT-PCR studies showing high levels of $\operatorname{Lrrc} 32 \mathrm{mRNA}$ in unstimulated $\mathrm{T}_{\text {regs }}$ relative to $\mathrm{T}_{\text {effs }}$, these data suggest that post-transcriptional mechanisms may play a role in controlling LRRC32 production and expression in non-activated $\mathrm{T}_{\text {regs }}$. Such post-transcriptional controls may be diminished upon stimulation via TCR/CD28 signaling, as indeed, upon stimulation, evidence of increased intracellular LRRC32 protein was evident in $\mathrm{T}_{\text {regs }}$ as assessed by flow cytometry (Figure 1d).

In addition, our signal peptide deletion construct studies reveal that the putative signal peptide in LRRC32 is critical for the cell surface expression of LRRC32, consistent with other reports that signal peptides are necessary for surface protein expression [33]. Our data showing that LRRC32 $\triangle$ SP is transcribed (Figure 4c) but not detected intracellularly (Figure $4 \mathrm{~b}$ ) suggest that LRRC32 $\triangle$ SP is rapidly broken down in the cytosol or is not translated at detectable levels following transcription. However, mechanisms for the rapid degradation of misfolded proteins exist to maintain cell viability, and as such, cytosolic LRRC32 $\Delta$ SP, unable to enter the endoplasmic reticulum owing to the lack of a signal peptide, may be translated but rapidly degraded afterwards by processes such as ubiquitination [34].

Finally, using freshly isolated, non-expanded CD4 ${ }^{+} \mathrm{CD} 25^{\mathrm{hi}}{ }_{\mathrm{LRRC}} 32^{+} \mathrm{T}_{\text {regs }}$, we show that such cells expressing surface LRRC32 appear to be functionally more suppressive than $\mathrm{CD} 4^{+} \mathrm{CD} 25^{\text {hi }}$ LRRC $32^{-} \mathrm{T}_{\text {regs }}$. Previous reports have shown that upon activation of $\mathrm{T}_{\text {effs, }}$, surface CD62L is usually decreased [35-37]. However, $\mathrm{T}_{\text {regs }}$ normally maintain CD62L expression and functional phenotype [38]. Furthermore, previous reports have shown that CD62L ${ }^{+} \mathrm{CD} 4{ }^{+} \mathrm{CD} 25^{\mathrm{hi}} \mathrm{T}_{\text {regs }}$ are more suppressive than their CD62 $\mathrm{L}^{-}$counterparts $[39,40]$. We show here that expression of surface CD62L appears to decrease significantly on $\mathrm{LRRC}^{+} \mathrm{T}_{\text {regs }}$ compared to LRRC32- $\mathrm{T}_{\text {reg }}$ populations.

Differences in CD62L processing may be responsible for the observed difference in CD62L expression between $\mathrm{LRRC} 2^{+}$and LRRC32 ${ }^{-}$activated $\mathrm{T}_{\text {regs. }}$. It has been shown that $90 \%$ of CD62L is rapidly cleaved from the surface within 4 hours of $\mathrm{T}$ cell activation prior to increasing over the next 48 hours, due to enhanced message stability, before ultimately decreasing due to downregulation of gene transcription [41]. Furthermore, it has been reported that CD62L is rapidly shed in $\mathrm{T}$ cells, including $\mathrm{T}_{\text {regs }}$, after activation $[42,43]$. In accordance, our data show that unstimulated LRRC32- CD4 ${ }^{+} \mathrm{CD} 25{ }^{\text {hi }} \mathrm{FoxP}^{+} \mathrm{T}_{\text {regs }}$ expressed more surface CD62L than stimulated LRRC $32^{+}$or LRRC $32^{-} \mathrm{CD} 4^{+} \mathrm{CD} 25^{\mathrm{hi}-}$ FoxP3 $^{+} \mathrm{T}_{\text {regs. }}$. However, upon activation, decreases in surface CD62L expression of LRRC32 ${ }^{+}$versus LRRC32cells were noted, suggesting that $\mathrm{LRRC} 2^{+}$cells are more activated compared to LRRC32- $\mathrm{T}_{\text {regs }}$. Given that an overnight stimulation is sufficient to induce LRRC32 expression on the cell surface of $\mathrm{T}_{\text {regs }}$, we chose this as our timepoint for phenotypic analysis. However, altering 
the time course of stimulation may also alter surface $\mathrm{T}_{\text {reg }}$ marker expression.

Activated $\mathrm{T}_{\text {regs }}$ that express LRRC32 may also represent a distinct population of more highly activatable $\mathrm{T}_{\text {regs }}$ compared to LRRC32- $\mathrm{T}_{\text {regs }}$ [41]. Indeed, our phenotypic studies using LRRC32 ${ }^{+}$and LRRC32- subsets of $\mathrm{T}_{\text {regs }}$ in the context of CD62L expression would appear to support the interpretation that $\mathrm{LRRC} 32^{+} \mathrm{T}_{\text {regs }}$, relative to LRRC32- $\mathrm{T}_{\text {regs }}$, are more prone to activation, as shown by increased cleavage of surface CD62L, and that this more highly activated state may translate into increased suppressive activity. Notably, although only a fraction of $\mathrm{T}_{\text {regs }}$ expressed LRRC32 upon activation overnight, these cells appeared to be more functionally suppressive than their LRRC32 counterparts.

Most natural FoxP3 ${ }^{+}$adult $\mathrm{T}_{\text {regs }}$ are $\mathrm{CD} 45 \mathrm{RO}^{+}$, and the expression of CD45RO is typically a marker of $\mathrm{T}$ cell activation $[44,45]$. As LRRC32 ${ }^{+} \mathrm{T}_{\text {regs }}$ appear to be more suppressive than LRRC32- $\mathrm{T}_{\text {regs }}$, it is possible that lower expression of CD45RO on LRRC32 $2^{+} \mathrm{T}_{\text {regs }}$ relative to LRRC32- $\mathrm{T}_{\text {regs }}$ may be due to increased auto-suppressive activity by LRRC32 ${ }^{+} \mathrm{T}_{\text {regs }}$ compared to LRRC32$\mathrm{T}_{\text {regs. }}$. As noted above, stimulated $\mathrm{T}_{\text {regs }}$ demonstrated expected increases in the surface expression of GITR, CD69, and CTLA4. GITR, or glucocorticoid-induced tumor necrosis factor receptor, was originally shown to be highly expressed on unactivated $\mathrm{T}_{\text {regs }}$ but relative to $\mathrm{T}_{\text {effs }}$, and its expression was increased upon cell activation [46-48]. It appears that GITR is a co-stimulatory molecule, and although it is preferentially expressed on CD25 ${ }^{\text {hi }}$ cells, it is also expressed at lower levels on $\mathrm{T}_{\text {effs }}$, and upon activation, $\mathrm{T}_{\text {effs }}$ can also upregulate GITR $[48,49]$. Hence, the use of GITR as a specific marker for $\mathrm{T}_{\text {regs }}$ appears to be limited. CD69 has been described in the context of a $\mathrm{CD} 69^{+} \mathrm{CD} 4^{+} \mathrm{CD} 25^{-} \mathrm{T}_{\text {reg }}$ subset that does not express Foxp3 but does express surface-bound TGF- $\beta 1$ in an ERK-dependent manner [50]. Normally, CD69 is upregulated upon T cell activation, and thus expected on our $\mathrm{T}_{\text {regs }}$ [50-52]. Since LRRC32 also binds LAP, thereby helping to concentrate TGF- $\beta 1$ at the cell surface, it is interesting to speculate whether CD69 in $\mathrm{T}_{\text {regs }}$ may play a role in helping to upregulate TGF- $\beta 1$ surface expression in the context of LRRC32 when the latter is available. Although our data did not find any significant differences in the CD69 expression in stimulated LRRC32 ${ }^{+}$and LRRC32- $\mathrm{T}_{\text {reg }}$ subsets (Figure $5 \mathrm{c}$ ), it is possible that part of the reason for the observed difference in suppressive activity between the LRRC $32^{+}$ and LRRC $\mathrm{T}^{-} \mathrm{T}_{\text {reg }}$ subsets may be in part due to synergy between CD69 and LRRC32 via increased surface expression of TGF- $\beta 1$. CTLA4, or cytotoxic T lymphocyte antigen-4, can inhibit $\mathrm{T}_{\text {eff }}$ activation via 1 ) binding B7.1 and B7.2, thereby depriving CD28 on $\mathrm{T}_{\text {effs }}$ of the ability to bind these co-stimulatory ligands, 2) inhibiting
IL-2 transcription and progression of cells through the cell cycle via inhibition of cyclin D3, cdk4, and cdk6 production, and 3) decreasing the amount of time the TCR is engaged [53-57]. As we did not see any significant differences in CTLA4 expression in the LRRC32 ${ }^{+}$ and LRRC32- $\mathrm{T}_{\text {reg }}$ subsets, we do not have data to suggest that differences in CTLA4 expression might have contributed to the observed differences in suppressive function in the LRRC $32^{+}$and LRRC32- $\mathrm{T}_{\text {reg }}$ subsets. Clearly, the results in this set of experiments raise many more interesting questions and suggest that the role of LRRC32 in the context of these other cell activation markers is complex.

Previous studies examining LRRC32 and T cell regulation have utilized $\mathrm{T}_{\text {effs }}$ transfected with constructs containing either wildtype $L r r c 32$ or Lrrc32 lacking leucine rich repeat regions, the signal peptide, the cytoplasmic domain, or Lrrc32 with a mutated cytoplasmic residue postulated to be part of a PDZ domain and thus thought to bind an intracellular protein $[8,25]$. These experiments were performed to address how LRRC32 may be processed and ultimately function in $\mathrm{T}_{\text {reg }}$ cells. PDZ domain mutation studies have suggested that the intracellular portion of LRRC32 is critical for surface expression, and other studies examined the LRRC32 deletion mutants in the context of downstream effector molecules such as FoxP3 $[8,25]$. These studies concluded that because FoxP3 expression was markedly decreased upon deletion of the leucine rich regions or the signal peptide, these regions were critical for LRRC32 function $[8,25]$. However, these studies never demonstrated actual cleavage of the putative signal peptide [8]. Here, we demonstrate via immunoprecipitation and confocal studies that LRRC32 encodes a signal peptide that is cleaved, and upon cleavage, allows mature LRRC32 to reach the cell surface.

It is likely that the LRRC32 signal peptide is cleaved from the newly translocated preprotein by type I eukaryotic endoplasmic reticulum signal peptidase, based upon the amino acid sequence of LRRC32 [58]. The initial amino acid sequence of LRRC32 incorporating a charged $\mathrm{N}$-terminal domain followed by a hydrophobic domain is consistent with published reports of the consensus motif for eukaryotic type I endoplasmic reticulum signal peptidase $[58,59]$. Furthermore, the sequence G-L-A at positions 15 though 17 of the preprotein is consistent with the $-3,-1$ rule, stating that residues at the -3 and -1 positions, relative to the cleavage site, must be neutral and have small side chains [58].

\section{Conclusions}

In summary, we have demonstrated a cleaved signal peptide site in LRRC32 is necessary for surface localization of native LRRC32 following activation of naturally- 
occurring freshly-isolated regulatory $\mathrm{T}$ cells. We show that $\mathrm{LRRC}_{2} 2^{+} \mathrm{CD} 44^{+} \mathrm{CD} 25^{\mathrm{hi}} \mathrm{FoxP}^{+} \mathrm{T}_{\text {regs }}$ express lower levels of surface CD62L compared to LRRC32 CD4 ${ }^{+} \mathrm{CD} 25^{\mathrm{hi}} \mathrm{FoxP}^{+} \mathrm{T}_{\text {regs }}$, suggesting that LRRC32 expression may alter surface expression of other activation markers of $\mathrm{T}$ cells such as CD62L. Finally, functional data demonstrate that LRRC32 $2^{+} \mathrm{T}_{\text {regs }}$ appear more suppressive compared to LRRC32- $\mathrm{T}_{\text {regs }}$, suggesting that LRRC32 surface expression may be useful as a marker that selects for more potent $\mathrm{T}_{\text {reg }}$ populations, although our data suggest that the functional difference in suppression between these two populations is not markedly robust. Hence, LRRC32 selection may be most useful when used in combination with other $\mathrm{T}_{\text {reg }}$ markers [60].

\section{Acknowledgements}

DVC was supported by NIH 2T32AR007569-16A (Program Director: KDC) and NIH 3P50AR055508-03S309 (DVC, TSM, and KDC). AKS was supported in part by the Dermatology Foundation. This research was also supported by $\mathrm{NIH}$ P30AR039750 (KDC). Flow cytometry was also supported by $\mathrm{NIH}$ P30CA43703 awarded to the Case Comprehensive Cancer Center. The authors wish to thank Christianne Sykes and Christy Malbasa, M.D. for their efforts in helping to procure patient samples, David Soler, Ph.D. for help in preparing cells, and Wendy Goodman, Ph.D. for critical review of the manuscript.

\section{Author details \\ ${ }^{1}$ Department of Dermatology, University Hospitals Case Medical Center and Case Western Reserve University, Cleveland, OH, 44106 USA. ${ }^{2}$ Department of Dermatology and Allergology, University of Szeged, Szeged, Hungary. ${ }^{3}$ Department of Dermatology, University of Yamanashi, Yamanashi, Japan. ${ }^{4}$ Statistical Sciences Core, Center For Clinical Investigation, Case Western Reserve University, Cleveland, OH, 44106 USA. ${ }^{5}$ VA Medical Center, Cleveland, $\mathrm{OH}, 44106$ USA. ${ }^{6}$ Current Address: Ohio State University Dermatology, 2012 Kenny Road, Columbus, OH, 43221, USA. ${ }^{7}$ Current Address: Department of Dermatology, Indiana University School of Medicine, 550 N. University Blvd., Suite 3240, Indianapolis, IN, 46202, USA.}

\section{Authors' contributions}

DVC, AKS, ABY, JVM, JO, HS, and EG performed experiments represented in this manuscript. DB provided statistical support. KDC, HS, and TSM provided valuable designed the study. DVC, TSM, and KDC drafted the manuscript. All authors read and approved the final manuscript.

Received: 26 October 2010 Accepted: 26 May 2011

Published: 26 May 2011

\section{References}

1. Bottcher RT, Pollet N, Delius H, Niehrs C: The transmembrane protein XFLRT3 forms a complex with FGF receptors and promotes FGF signalling. Nat Cell Biol 2004, 6(1):38-44.

2. Ollendorff V, Szepetowski P, Mattei MG, Gaudray P, Birnbaum D: New gene in the homologous human 11q13-q14 and mouse 7F chromosomal regions. Mamm Genome 1992, 2(3):195-200.

3. Ollendorff $V$, Noguchi T, deLapeyriere O, Birnbaum D: The GARP gene encodes a new member of the family of leucine-rich repeat-containing proteins. Cell Growth Differ 1994, 5(2):213-219.

4. Bekri S, Adelaide J, Merscher S, Grosgeorge J, Caroli-Bosc F, PeruccaLostanlen D, Kelley PM, Pebusque MJ, Theillet C, Birnbaum D, et al: Detailed map of a region commonly amplified at 11q13->q14 in human breast carcinoma. Cytogenet Cell Genet 1997, 79(1-2):125-131.

5. Merscher S, Bekri S, de Leeuw B, Pedeutour F, Grosgeorge J, Shows TB, Mullenbach R, Le Paslier D, Nowak NJ, Gaudray P, et al: A 5.5-Mb highresolution integrated map of distal 11q13. Genomics 1997, 39(3):340-347.
6. Roubin R, Pizette S, Ollendorff V, Planche J, Birnbaum D, Delapeyriere O: Structure and developmental expression of mouse Garp, a gene encoding a new leucine-rich repeat-containing protein. Int J Dev Biol 1996, 40(3):545-555.

7. Chang MX, Nie P, Xie HX, Sun BJ, Gao Q: Characterization of two genes encoding leucine-rich repeat-containing proteins in grass carp Ctenopharyngodon idellus. Immunogenetics 2005, 56(10):710-721.

8. Wang R, Wan Q, Kozhaya L, Fujii H, Unutmaz D: Identification of a regulatory $T$ cell specific cell surface molecule that mediates suppressive signals and induces Foxp3 expression. PLOS ONE 2008, 3(7):e2705.

9. Somani A, Young A, Sugiyama H, Bookout A, Lam M, Cooper K, McCormick T: Characterization of glycoprotein A repetition predominant protein (GARP) identified as a novel gene marker of human CD4 +CD25high regulatory T cells (Treg). 2008 International Investigative Dermatology Meeting 2008.

10. Wang R, Kozhaya L, Mercer F, Khaitan A, Fujii H, Unutmaz D: Expression of GARP selectively identifies activated human FOXP3+ regulatory T cells. Proc Natl Acad Sci USA 2009, 106(32):13439-13444.

11. Tran DQ, Andersson J, Wang R, Ramsey H, Unutmaz D, Shevach EM: GARP (LRRC32) is essential for the surface expression of latent TGF-beta on platelets and activated FOXP3+ regulatory T cells. Proc Natl Acad Sci USA 2009, 106(32):13445-13450.

12. Tran DQ, Andersson J, Hardwick D, Bebris L, Illei GG, Shevach EM: Selective expression of latency-associated peptide (LAP) and IL-1 receptor type I/II (CD121a/CD121b) on activated human FOXP3+ regulatory $T$ cells allows for their purification from expansion cultures. Blood 2009, 113(21):5125-5133.

13. Stockis J, Colau D, Coulie PG, Lucas S: Membrane protein GARP is a receptor for latent TGF-beta on the surface of activated human Treg. Eur $\mathrm{J}$ Immunol 2009, 39(12):3315-3322.

14. Nakamura K, Kitani A, Strober W: Cell contact-dependent immunosuppression by $\mathrm{CD} 4(+) \mathrm{CD} 25(+)$ regulatory $\mathrm{T}$ cells is mediated by cell surface-bound transforming growth factor beta. J Exp Med 2001, 194(5):629-644.

15. Takahashi T: Immunologic self-tolerance maintained by CD25+CD4+ regulatory $\mathrm{T}$ cells constitutively expressing cytotoxic $\mathrm{T}$ lymphocyteassociated antigen 4. J Exp Med 2000, 192:303-310.

16. Nishizuka Y, Sakakura T: Thymus and reproduction: sex-linked dysgenesia of the gonad after neonatal thymectomy in mice. Science 1969, 166:753-755.

17. Hori S, Nomura T, Sakaguchi S: Control of regulatory T cell development by the transcription factor Foxp3. Science 2003, 299:1057-1061.

18. Sakaguchi S: Immunologic self-tolerance maintained by activated T cells expressing IL-2 receptor [alpha]-chains (CD25). J Immunol 1995, 155:1151-1164.

19. Schwartz RH: Natural regulatory T cells and self-tolerance. Nat Immunol 2005, 6(4):327-330.

20. Fontenot JD, Gavin MA, Rudensky AY: Foxp3 programs the development and function of CD4+CD25+ regulatory T cells. Nat Immunol 2003, 4:330-336.

21. Khattri R, Cox T, Yasayko SA, Ramsdell F: An essential role for Scurfin in CD4+CD25+ T regulatory cells. Nat Immunol 2003, 4:337-342.

22. Bachmann MF: Cutting edge: lymphoproliferative disease in the absence of CTLA-4 is not T cell autonomous. J Immunol 1999, 163:1128-1131.

23. Sugiyama H, Gyulai R, Toichi E, Garaczi E, Shimada S, Stevens SR, McCormick TS, Cooper KD: Dysfunctional Blood and Target Tissue CD4 +CD25high Regulatory T Cells in Psoriasis: Mechanism Underlying Unrestrained Pathogenic Effector T Cell Proliferation. J Immunol 2005, 174(1):164-173.

24. Dyrløv Bendtsen J, Nielsen H, von Heijne G, Brunak S: Improved Prediction of Signal Peptides: SignalP 3.0. Journal of Molecular Biology 2004, 340(4):783-795.

25. Probst-Kepper M, Geffers R, Kroger A, Viegas N, Erck C, Hecht HJ, Lunsdorf H, Roubin R, Moharregh-Khiabani D, Wagner K, et al: GARP: a key receptor controlling FOXP3 in human regulatory $\mathrm{T}$ cells. J Cell Mol Med 2009, 13:13.

26. Emanuelsson $\mathrm{O}$, Brunak S, von Heijne G, Nielsen H: Locating proteins in the cell using TargetP, SignalP and related tools. Nat Protoc 2007, 2(4):953-971. 
27. Gilmore R, Blobel G, Walter P: Protein translocation across the endoplasmic reticulum. I. Detection in the microsomal membrane of a receptor for the signal recognition particle. J Cell Biol 1982, 95(2 Pt 1):463-469.

28. Gilmore R, Walter P, Blobel G: Protein translocation across the endoplasmic reticulum. II. Isolation and characterization of the signal recognition particle receptor. J Cell Biol 1982, 95(2 Pt 1):470-477.

29. La Cava A: T-regulatory cells in systemic lupus erythematosus. Lupus 2008, 17(5):421-425.

30. Salomon B, Lenschow DJ, Rhee L, Ashourian N, Singh B, Sharpe A Bluestone JA: B7/CD28 costimulation is essential for the homeostasis of the CD4+CD25+ immunoregulatory $T$ cells that control autoimmune diabetes. Immunity 2000, 12(4):431-440.

31. Janine LC, Nicholas JR, Kevin JM, Holm HU, Fiona P: Regulatory T cells and intestinal homeostasis. Immunological Reviews 2005, 204(1):184-194.

32. Tran DQ, Shevach EM: Therapeutic potential of FOXP3+ regulatory $T$ cells and their interactions with dendritic cells. Human Immunology 2009, 70(5):294-299.

33. Couvineau A, Rouyer-Fessard C, Laburthe M: Presence of a N-terminal signal peptide in class II G protein-coupled receptors: crucial role for expression of the human VPAC1 receptor. Regulatory Peptides 2004, 123(1-3):181-185.

34. Goldberg AL: Protein degradation and protection against misfolded or damaged proteins. Nature 2003, 426(6968):895-899.

35. Mascarell $L$, Truffa-Bachi P: T lymphocyte activation initiates the degradation of the CD62L encoding mRNA and increases the transcription of the corresponding gene. Immunol Lett 2004, 94(12):115-122.

36. Gerberick GF, Cruse LW, Miller CM, Sikorski EE, Ridder GM: Selective Modulation of T Cell Memory Markers CD62L and CD44 on Murine Draining Lymph Node Cells Following Allergen and Irritant Treatment. Toxicology and Applied Pharmacology 1997, 146(1):1-10.

37. Gomes-Pereira S, Rodrigues OR, Santos-Gomes GM: Dynamics of CD62L/ CD45RB CD4+ and CD8+ lymphocyte subsets in hepatic and splenic tissues during murine visceral leishmaniasis. Immunology Letters 2004, 95(1):63-70.

38. Strauss L, Bergmann C, Whiteside TL: Functional and phenotypic characteristics of CD4+CD25highFoxp3+ Treg clones obtained from peripheral blood of patients with cancer. Int J Cancer 2007, 121(11):2473-2483.

39. Lepault F, Gagnerault MC: Characterization of Peripheral Regulatory CD4+ T Cells That Prevent Diabetes Onset in Nonobese Diabetic Mice. J Immunol 2000, 164(1):240-247.

40. Fu S, Yopp AC, Mao X, Chen D, Zhang N, Mao M, Ding Y, Bromberg JS: CD4+ CD25+ CD62+ T-regulatory cell subset has optimal suppressive and proliferative potential. Am J Transplant 2004, 4(1):65-78.

41. Chao CC, Jensen R, Dailey MO: Mechanisms of L-selectin regulation by activated T cells. J Immunol 1997, 159(4):1686-1694.

42. Guo Z, Jang MH, Otani K, Bai Z, Umemoto E, Matsumoto M, Nishiyama M, Yamasaki M, Ueha S, Matsushima K, et al: CD4+CD25+ regulatory T cells in the small intestinal lamina propria show an effector/memory phenotype. Int Immunol 2008, 20(3):307-315.

43. Tang Q, Bluestone JA: The Foxp3+ regulatory $\mathrm{T}$ cell: a jack of all trades, master of regulation. Nat Immunol 2008, 9(3):239-244.

44. Akbar AN, Terry L, Timms A, Beverley PC, Janossy G: Loss of CD45R and gain of UCHL1 reactivity is a feature of primed T cells. J Immunol 1988, 140(7):2171-2178.

45. Booth NJ, McQuaid AJ, Sobande T, Kissane S, Agius E, Jackson SE, Salmon M, Falciani F, Yong K, Rustin MH, et al: Different proliferative potential and migratory characteristics of human CD4+ regulatory $\mathrm{T}$ cells that express either CD45RA or CD45RO. J Immunol 2010, 184(8):4317-4326.

46. McHugh RS, Whitters MJ, Piccirillo CA, Young DA, Shevach EM, Collins M, Byrne MC: CD4(+)CD25(+) immunoregulatory T cells: gene expression analysis reveals a functional role for the glucocorticoid-induced TNF receptor. Immunity 2002, 16(2):311-323.

47. Shimizu J, Yamazaki S, Takahashi T, Ishida Y, Sakaguchi S: Stimulation of CD25(+)CD4(+) regulatory T cells through GITR breaks immunological self-tolerance. Nat Immunol 2002, 3(2):135-142.

48. Ermann J, Fathman CG: Costimulatory signals controlling regulatory $\mathrm{T}$ cells. Proc Natl Acad Sci USA 2003, 100(26):15292-15293.
49. Tone M, Tone Y, Adams E, Yates SF, Frewin MR, Cobbold SP, Waldmann H: Mouse glucocorticoid-induced tumor necrosis factor receptor ligand is costimulatory for T cells. Proc Natl Acad Sci USA 2003, 100(25):15059-15064.

50. Han Y, Guo Q, Zhang M, Chen Z, Cao X: CD69+ CD4+ CD25- T cells, a new subset of regulatory $T$ cells, suppress $T$ cell proliferation through membrane-bound TGF-beta 1. J Immunol 2009, 182(1):111-120.

51. De Maria R, Cifone MG, Trotta R, Rippo MR, Festuccia C, Santoni A, Testi R: Triggering of human monocyte activation through CD69, a member of the natural killer cell gene complex family of signal transducing receptors. J Exp Med 1994, 180(5):1999-2004.

52. Sancho D, Gomez M, Sanchez-Madrid F: CD69 is an immunoregulatory molecule induced following activation. Trends Immunol 2005, 26(3):136-140.

53. Brunner MC, Chambers CA, Chan FK, Hanke J, Winoto A, Allison JP: CTLA-4Mediated inhibition of early events of T cell proliferation. J Immunol 1999, 162(10):5813-5820.

54. Friedline $\mathrm{RH}$, Brown DS, Nguyen $\mathrm{H}$, Kornfeld $\mathrm{H}$, Lee J, Zhang $Y$, Appleby $M$, Der SD, Kang J, Chambers CA: CD4+ regulatory T cells require CTLA-4 for the maintenance of systemic tolerance. J Exp Med 2009, 206(2):421-434.

55. Ostrov DA, Shi W, Schwartz JC, Almo SC, Nathenson SG: Structure of murine CTLA-4 and its role in modulating $T$ cell responsiveness. Science 2000, 290(5492):816-819.

56. van der Merwe PA, Bodian DL, Daenke S, Linsley P, Davis SJ: CD80 (B7-1) binds both CD28 and CTLA-4 with a low affinity and very fast kinetics. J Exp Med 1997, 185(3):393-403.

57. Schneider H, Downey J, Smith A, Zinselmeyer BH, Rush C, Brewer JM, Wei B, Hogg N, Garside P, Rudd CE: Reversal of the TCR stop signal by CTLA-4. Science 2006, 313(5795):1972-1975.

58. Tuteja R: Type I signal peptidase: An overview. Archives of Biochemistry and Biophysics 2005, 441(2):107-111.

59. von Heijne G: The signal peptide. J Membr Biol 1990, 115(3):195-201

60. Liu W, Putnam AL, Xu-Yu Z, Szot GL, Lee MR, Zhu S, Gottlieb PA, Kapranov P, Gingeras TR, Fazekas de St Groth B, et al: CD127 expression inversely correlates with FoxP3 and suppressive function of human CD4 + T reg cells. J Exp Med 2006, 203(7):1701-1711.

doi:10.1186/1471-2091-12-27

Cite this article as: Chan et al:: Signal peptide cleavage is essential for surface expression of a regulatory $T$ cell surface protein, leucine rich repeat containing 32 (LRRC32). BMC Biochemistry 2011 12:27.

\section{Submit your next manuscript to BioMed Central and take full advantage of:}

- Convenient online submission

- Thorough peer review

- No space constraints or color figure charges

- Immediate publication on acceptance

- Inclusion in PubMed, CAS, Scopus and Google Scholar

- Research which is freely available for redistribution

Submit your manuscript at www.biomedcentral.com/submit
C Biomed Central 